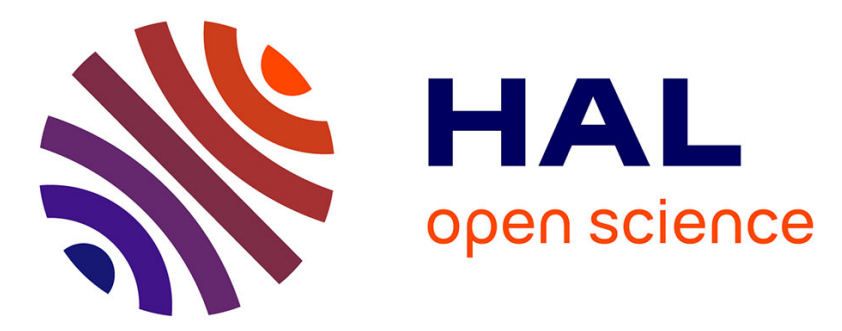

\title{
ATP storage and uptake by isolated pancreatic zymogen granules
}

Kristian A. Haanes, Ivana Novak

\section{To cite this version:}

Kristian A. Haanes, Ivana Novak. ATP storage and uptake by isolated pancreatic zymogen granules. Biochemical Journal, 2010, 429 (2), pp.303-311. 10.1042/BJ20091337 . hal-00495490

\section{HAL Id: hal-00495490 \\ https://hal.science/hal-00495490}

Submitted on 28 Jun 2010

HAL is a multi-disciplinary open access archive for the deposit and dissemination of scientific research documents, whether they are published or not. The documents may come from teaching and research institutions in France or abroad, or from public or private research centers.
L'archive ouverte pluridisciplinaire HAL, est destinée au dépôt et à la diffusion de documents scientifiques de niveau recherche, publiés ou non, émanant des établissements d'enseignement et de recherche français ou étrangers, des laboratoires publics ou privés. 


\title{
ATP storage and uptake by isolated pancreatic zymogen granules
}

\author{
Kristian A. Haanes and Ivana Novak* \\ From the Department of Biology, August Krogh Building, Universitetsparken 13, University of \\ Copenhagen, DK-2100 Copenhagen Ø, Denmark
}

Page heading: ATP storage and uptake by pancreatic zymogen granules

\begin{abstract}
ATP is released from pancreatic acini in response to cholinergic and hormonal stimulation. The same stimuli cause exocytosis of zymogen granules (ZG) and release of digestive enzymes. This study aimed to determine whether ZG stored ATP and to characterize the uptake mechanism for ATP transport into the ZG. ZG were isolated and ATP content was measured using luciferin/luciferase assay and related to protein in the sample. The estimate of ATP concentration in freshly isolated granules was 40 to $120 \mu \mathrm{M}$. The ATP uptake had an apparent $K_{m}$ of $4.9 \pm 2.1 \mathrm{mM}$ when granules were incubated without $\mathrm{Mg}^{2+}$ and a $K_{m}$ of $0.47 \pm 0.05 \mathrm{mM}$ in the presence of $\mathrm{Mg}^{2+}$, both at $\mathrm{pH} 6.0$ buffers. The uptake of ATP was significantly higher at $\mathrm{pH}$ 7.2 compared to $\mathrm{pH}$ 6.0 solutions. The anion transport blockers DIDS and Evans blue inhibited ATP transport. Western blot on ZG showed the presence of the vesicular nucleotide transporter, VNUT. Together, these findings indicate that VNUT may be responsible for the ATP uptake into the ZG. Furthermore, this study shows the presence of ATP together with digestive enzymes in ZG. This indicates that co-released ATP would regulate $P 2$ receptors in pancreatic ducts, and thus ductal secretion, and this would aid delivery of enzymes to duodenum.
\end{abstract}

\section{INTRODUCTION}

ATP is an extracellular signal that stimulates purinergic receptors in many different tissues. In exocrine pancreas, ATP is released from acini and it regulates function of pancreatic ducts, which express a number of purinergic receptors including $\mathrm{P} 2 \mathrm{Y}_{2}, \mathrm{P}_{2} \mathrm{Y}_{4}, \mathrm{P} 2 \mathrm{X}_{4}$ and $\mathrm{P} 2 \mathrm{X}_{7}[1,2]$. It is not known how ATP is released, but there are two interesting observations that indicate that zymogen granules (ZG) might be involved. Acetylcholine and cholecystokinin, well established agonists of acinar zymogen secretions, also stimulate release of ATP [1,2]. Bioimaging experiments with ATP markers (quinacrine and fluorescent ATP analogues) indicate that ATP is stored in vesicle compartments possibly in ZG [1] .

Zymogen granules are complex organelles that contain more than 20 different proteins, most of them digestive enzymes [3]. Recent proteomics studies of the ZG membrane revealed the presence of more than 100 different proteins [3,4]. However, only few functional membrane proteins have been identified. One of the most important, is the vacuolar-type $\mathrm{H}^{+}$-ATPase, which acidifies the ZG [5], although the $\mathrm{pH}$ status may depend on the maturity of the granule [6]. Other functional ZG membrane proteins described are $65-\mathrm{kDa}$ mdr1 regulated $\mathrm{K}^{+}(\mathrm{KCNQ} 1)$ and $\mathrm{Cl}^{-}(\mathrm{ClC}-2)$ channels, $\mathrm{Ca}^{2+}$ release channels, $\mathrm{Ca}^{2+}$-activated anion channels and non-selective cation channels [7].

Release of ATP to the extracellular medium is believed to take place through two different release mechanisms or it can be a combination of the two [8]. The first type of release, considered especially in non-secretory cells, is the non-vesicular ATP release that can take place via ion channels or transporters. Many candidates have been put forward and among these are connexins [9], pannexins [10], P2X $\mathrm{X}_{7}$ receptors [11,12], CFTR [13] and maxi-anion channels [14]. The second type of ATP release is via vesicular transport, such as regulated vesicular exocytosis that has been described for endocrine cells [15] and nerve endings [16], both of which produce specialized products like hormones and transmitters. In epithelial cells, ATP release has also been observed as co-release with 
mucin in Calu-3 cells [17]. In addition, vesicular ATP release has been observed in non-secretory cells [18], and release via constitutive vesicular trafficking has also been suggested [19].

One important question is how ATP is accumulated inside vesicles, and since it is a highly charged molecule, there must be a transporter that carries it across the vesicular membrane. The presence of a vesicular transport mechanism for ATP has been postulated for more than 30 years [20], but the protein responsible for the vesicular accumulation remained unknown. Recently, it was discovered that the orphan transporter SLC17A9 was an ATP transporter [21]. This transporter, expressed in the brain and adrenal glands (particularly on chromaffin granules), was called the vesicular nucleotide transporter (VNUT).

The aim of the present study was to establish whether ATP is stored in the zymogen granules of pancreatic acini and characterize the uptake mechanism with regards to ionic gradients, inhibitor sensitivity and VNUT characteristics. In order to approximate the in vivo conditions, we worked with intact ZG rather than ghosts. This required the development of ATP assay that was not affected by digestive enzymes. The experiments presented here show ATP uptake into ZG, and this process is dependent on $\mathrm{pH}$ and has a pharmacological signature of VNUT.

\section{EXPERIMENTAL}

\section{Preparation and characterization of zymogen granules}

The pancreas was removed from male Wistar rats that were fasted overnight and killed by cervical dislocation. Procedures were approved by the Danish Animal Experiment Inspectorate (Dyreforsøgstilsynet). All subsequent isolation procedures were carried out at $4^{\circ} \mathrm{C}$. ZG were isolated according to a previously established method with slight modifications $[4,22]$. Briefly, the pancreas was trimmed free of fat, cut into smaller pieces and homogenized in sucrose-MES-EGTA (SME) control buffer containing in mmol/1: sucrose 250; $14 \mathrm{Na}^{+}$, MES 25; EGTA 2; $0.1 \mathrm{mg} / \mathrm{ml}$ soybean trypsin inhibitor; $\mathrm{pH}$ was 6.0 . All buffers were balanced with sucrose to $315 \mathrm{mmol} / \mathrm{kg}$. In order to deactivate trypsin during ZG preparation and experimental protocols, all samples were incubated with soybean trypsin inhibitor and the incubation buffer was $\mathrm{pH}$ 6.0, far from the trypsin $\mathrm{pH}$ optimum.

Tissue homogenization was performed with glass-teflon homogenizer at $1,000 \mathrm{rev} / \mathrm{min}$. The homogenate was centrifuged at $250 \mathrm{~g}$ for $5 \mathrm{~min}$ and supernatant was centrifuged at 1,400 $\mathrm{g}$ for $7 \mathrm{~min}$ to obtain the crude ZG (Ole Dich microcentrifuge). Crude ZG were centrifuged on a $50 \%$ Percoll gradient for $20 \mathrm{~min}$ at $60,000 \mathrm{~g}(25,000 \mathrm{rpm}$ Beckmann Ultracentrifuge 70.1 rotor). The ZG fraction containing Percoll was collected from the dense white band near the bottom of the tube. This fraction was washed with 6 volumes of SME buffer and centrifuged at 2,000 $\mathrm{g}$ for $10 \mathrm{~min}$ and wash was repeated two more times.

Protein was determined with Coomassie (Bradford) Protein Assay Kit (Pierce) according to manufacturers of the kit and measured in an Eppendorf Biophotometer with a standard curve with 0 $2 \mathrm{mg} / \mathrm{ml}$ protein. Amylase assays were conducted on diluted samples with EnzChek ${ }^{\circledR}$ Ultra Amylase Assay Kit (Invitrogen). Amylase content was determined according to the kit manufacturers, with standard curve from 0 to $100 \mathrm{mU}$ of amylase. Fluorescence was measured in a FLUOStar Optima (BMG Labtech).

In order to confirm the identity of the fraction selected from the Percoll centrifugation as ZG, ZG were stained with Rab3D antibody according to the protocol adapted from Chen and co-workers [23]. Briefly, purified ZG were re-suspended in small volume of SME and transferred to a coverglass $(0.17$ $\pm 0.01 \mathrm{~mm}$ thickness) and allowed to bind for $10 \mathrm{~min}$. The same volume of $8 \%$ paraformaldehyde was then added and incubated for 1 hour at room temperature. Samples were rinsed and blocked with 5\% BSA. Goat-antibody for Rab3D (SantaCruz Biotechnology) was then applied (1:200) for 1.5 hours at room temperature. Subsequently, the secondary antibody Alexa 568 conjugated to donkey anti-goat 
(Invitrogen) was applied (1:200). Samples were fixed with propyl gallate in glycerine/PBS. The slides were viewed with 100x oil objective in a Nikon microphot-FXA microscope and pictures obtained and analyzed with Nikon NIS elements.

\section{ATP determinations and transport assay}

The basic control buffer with/without ATP for ZG incubation was the SME buffer supplemented with $4 \mathrm{mM} \mathrm{KCl}$ and it was used unless otherwise stated. For $\mathrm{Mg}^{2+}$ samples some of the $\mathrm{NaOH}$ was replaced with $\mathrm{Mg}(\mathrm{OH})_{2}$ to give the desired $\mathrm{Mg}^{2+}$ concentration $(0-4 \mathrm{mM})$. The relatively nonphysiological SME buffer was chosen to keep ZG stable. In some series of experiments, buffers with varying $\mathrm{pH}$ values were used and they contained in mmol/1: sucrose $200, \mathrm{Na}^{+} 14$, MES 5, HEPES 5, ATP 4, EGTA 2, $\mathrm{KCl} \mathrm{4}$, and $0.1 \mathrm{mg} / \mathrm{ml}$ trypsin inhibitor; $\mathrm{pH}$ was adjusted to $6.0,7.2$ or 8.0 with the addition of $\mathrm{NaOH}$. The high chloride buffer used contained in mmol/l: $\mathrm{Cl}^{-} 130, \mathrm{Na}^{+} 14, \mathrm{~K}^{+} 4$, NMDG 140, MES 25, EGTA 2, ATP 4, $0.1 \mathrm{mg} / \mathrm{ml}$ trypsin inhibitor, $\mathrm{pH}$ was adjusted to 6.0 and osmolality was $\sim 315 \mathrm{mmol} / \mathrm{kg}$.

Incubation of ZG with ATP was performed by adding a small volume of highly concentrated ZG to 1 $\mathrm{ml}$ of incubation buffer in a $1.5 \mathrm{ml}$ Eppendorf tube and the sample was set to incubate for $30 \mathrm{~min}$ at $37^{\circ} \mathrm{C}$. Incubation was ended by a centrifugation at $4^{\circ} \mathrm{C}$ at $2,000 \mathrm{~g}$ for $10 \mathrm{~min}$. The incubation buffer was changed with SME buffer for washing and ZG were pelleted and re-suspended in fresh SME buffer; this was done 3 times to remove exogenous ATP. The pellet was recovered from the final wash and re-suspended in $150 \mu 1$ of SME buffer and moved to a new Eppendorf tube. These $150 \mu 1$ samples were centrifuged again and ZG formed a pellet. $75 \mu$ sample of the buffer (background sample) was collected for measurements of background ATP and protein, before the pellet was resuspended in the $75 \mu \mathrm{l}$ remaining (ZG sample). The procedure for measuring ATP and protein was then the same for both ZG and background control. On each $75 \mu 1$, first $30 \mu 1$ was used to measure protein using the Bradford assay. Lysing before this step was unnecessary as granules lyse in the very acidic kit. The remaining $45 \mu \mathrm{l}$ was heated to $98^{\circ} \mathrm{C}$ for 1.5 minutes to lyse the granules and to inactivate all enzymes, both potential ATPases and digestive enzymes. Then ATP measurements were then conducted using $20 \mu \mathrm{l}$ in duplicates.

ATP was determined using the established luciferin/luciferase luminescence assay with the ATP kit SL 144-041 (Biothema). For each run, standard curves were made with ATP ranging from $10^{-9} \mathrm{M}$ to $10^{-5} \mathrm{M}$ and standards were diluted in the same buffer as the samples and heated to $98^{\circ} \mathrm{C}$ for 1.5 minutes. Samples were placed in microtiter plates and luminescence was recorded individually and immediately at 1 second sampling rate in FLUOStar Optima for all samples.

The following inhibitors and ionophores were used in this study: 4,4' Diisothiocyanatostilbene-2,2'disulfonic acid (DIDS) at $100 \mu \mathrm{M}$, bafilomycin A1 at $400 \mathrm{nM}$, Carbonyl cyanide 3chlorophenylhydrazone (CCCP) at $5 \mu \mathrm{M}$, valinomycin at $5 \mu \mathrm{M}$, Evans blue at $100 \mu \mathrm{M}$ and ARL 67156 at $100 \mu \mathrm{M}$. Some inhibitors were dissolved in DMSO, and there was no effect of DMSO $(0.1 \%)$ on the ATP uptake (data not shown). There was no effect of the inhibitors on the luminescence assay, as the ZG samples were washed prior to assay, as checked by internal standards.

\section{Western blot for VNUT}

Isolated ZG membrane, used for Western blot, only was isolated by method of Chen and Andrews [22]. Briefly zymogen granules were re-suspended in buffer containing (in mmol/1): 150 sodium acetate, 10 MOPS, $0.1 \mathrm{MgSO}_{4}$ at $\mathrm{pH} 7.0$ together with $27 \mu \mathrm{g} / \mathrm{ml}$ nigericin. This lysed granules after incubation at $37^{\circ} \mathrm{C}$ for $15 \mathrm{~min}$. The lysate was centrifuged at $38,000 \mathrm{rpm}$ for 1 hour in a Beckman ultracentrifuge ( $\mathrm{Ti} 70.1$ rotor) to pellet the zymogen granule membrane. To remove absorbed zymogens, the ZG membrane pellet was washed with $250 \mathrm{mmol} / \mathrm{KBr}$ and re-centrifuged to pellet the membrane. This pellet was then washed in $100 \mathrm{mM} \mathrm{Na}_{2} \mathrm{CO}_{3}$ at $\mathrm{pH} \mathrm{11}$, and centrifuged for a final time. All solutions contained 1x Sigma protease inhibitor (S-8820). 
Western blot samples were denatured $\left(70^{\circ} \mathrm{C}\right)$ and reduced $(50 \mathrm{mM}$ DTT) and then run in a precasted gel from Invitrogen. Buffers were created from stock solutions provided by Invitrogen. The membrane was blocked overnight at $4^{\circ} \mathrm{C}$ in $0.5 \%$ Milk powder and $1 \%$ BSA together with $0.1 \%$ Tween20. Primary antibody for Slc17A9/VNUT (a kind gift from Professor Y. Moriyama) was added in a 1:1000 dilution in blocking buffer for 1 hour. The secondary antibody was anti-rabbit conjugated horse-radish peroxidase antibody (1:2500 dilution) in blocking buffer and incubated for 1 hour. The blot was then cleaned with $3 \times 5$ minutes with water, 5 minutes in TS buffer containing $0.05 \%$ Tween 20. Finally, the blot was washed for 1 hour in $2 \% \mathrm{NaCl} \mathrm{w} / \mathrm{v}$ in TS buffer. Before adding enzyme substrate, the blot was washed for 30 minutes in water. The blot was then viewed by exposure to a film (General Electrics). CD39 antibody from SantaCruz (1:100) and $\alpha$-amylase from Sigma (1:1000) was used for Western blot controls. (A-8273). For CD39, the secondary antibody was anti-goat conjugated horse-radish peroxidase antibody (1:2500 dilution). For amylase, same conditions as for VNUT was applied.

\section{Statistics}

ATP was measured in duplicates and samples were pooled for each individual experiment. Each $n$ refers to numbers of experiments on ZG isolated from different animals. All numbers are mean \pm S.E.M. To test statistical significance unpaired two-tail student's $t$-tests were applied and $\mathrm{P}<0.05$ was considered significant. Data and statistics were analyzed with Origin Lab 7 software. Free ATP calculation is based on the program Bound and Determined, BAD.exe [24].

\section{RESULTS}

\section{Characterization of ZG preparation}

In order to measure ATP, the first task was to isolate and purify ZG. We adopted the method of Chen and co-workers [4,22], previously used for proteomics analysis, where high purity of ZG is essential. Figure 1 shows the picture of $\mathrm{ZG}$ that were isolated from rat pancreas and stained with antibody directed against Rab3D, which is a small G-protein found selectively in the ZG membrane and involved in regulated exocytosis [25]. We also determined amylase activity and it was found to be upconcentrated about five fold relative to total protein after the purification (data not shown). This value is similar to those reported elsewhere $[26,27,28]$.

Following isolation of high purity ZG, the next step was to optimize an assay for ATP measurements. We used a well established luminescence method for detecting ATP (luciferase/luciferin), but first experiments with untreated ZG showed that it was difficult to get stable ATP signals and ATP appeared to be low unless measured immediately. Figure 2 shows such original luminescence measurements, where ATP was added to a control buffer or to ZG. In the control buffer luminescence increased with the addition of extra ATP (Fig. 2A). In the presence of ZG the ATP signal was unstable, as luminescence decreased faster than the $1 \%$ per min decay reported by the kit manufactures (Fig. 2B). Furthermore, additions of the same amount of exogenous ATP did not bring luminescence up to starting levels; on the contrary the signal was lower with each addition of ATP. However, addition of more luciferase/luciferin $(t=55 \mathrm{~min})$ increased the luminescence up to the level seen in the control buffer without ZG at comparable time (Fig. 2A).

These experiments clearly indicate that rather than loss of ATP, due to activity of possible ATPases on the $Z G$ membrane, it was the disappearance of luciferase that caused the rapid decrease in luminescence. Most likely, trypsin and other trypsin-activated digestive proteases from ZG digested luciferase in the ATP assay. The proteolysis may have been favoured in the ATP assay solution, which had $\mathrm{pH} 8$ and were near the $\mathrm{pH}$ optimum for trypsin [29]. Since general proteolysis-inhibitors were not applicable in the assay, due to their interference with luminescence, we used the heatinactivation approach. ATP is stable at high temperatures, as standard curves obtained with heattreated and normal ATP were the same (data not shown). Therefore, trypsin was deactivated by 
heating the samples to $98^{\circ} \mathrm{C}$ for 1.5 minutes prior to ATP measurements. This treatment gave stable luminescence signals and better detection of ATP.

Next, it was important to determine whether the number of ZG (related to the protein concentration) was proportional to the ATP concentration. Figure 3 shows that there is linear relation between the total protein $(\mu \mathrm{g} / \mathrm{ml})$ and ATP concentration $(\mathrm{nM})$ in the sample. The ATP/protein ratio was unchanged for the samples incubated under the same conditions, and therefore it is a valid assumption that changes in ATP/protein ratio is a good measure of ATP concentration in ZG. Since ZG can have different stability, depending on the incubation buffer, only the ZG that could be centrifuged to form a pellet were left for ATP measurements. Therefore, incubation of ZG in different buffers and with inhibitors did not alter the assay suitability, since the measurements were based on relative protein/ATP ratios after a thorough wash of the ZG.

\section{Uptake of ATP and the effect of inhibitors}

Successful isolation of high purity ZG and stable levels of ATP measurements permitted further studies on the ZG. In the first experiments we show that the freshly isolated ZG that were not incubated with any ATP contained an endogenous ATP concentration of $93 \pm 12 \mathrm{pmol} / \mathrm{mg}(\mathrm{n}=6)$. Next experiments were designed to study ATP transport across the ZG membrane. The ZG were incubated for 30 min with different ATP concentrations without $\mathrm{Mg}^{2+}$ and with ATP ranging from 0 to $8 \mathrm{mM}$ (total), which are concentrations within the expected cytosolic range. Figure 4A shows the ATP uptake into ZG after endogenous ATP was measured and subtracted from each individual experimental series. The endogenous ATP, measured in a sample that had been incubated for 30 minutes with no exogenous ATP, had a value of $76 \pm 16 \mathrm{pmol} / \mathrm{mg}(\mathrm{n}=6)$ and is close to the values obtained in freshly isolated ZG (see above). The data were fitted with an Eadie-Hofstee plot. An apparent $\mathrm{K}_{\mathrm{m}}$ of $4.9 \pm 2.1$ and a $\mathrm{V}_{\max }$ of $850 \pm 250 \mathrm{pmol} / \mathrm{mg} / 30 \mathrm{~min}$ was obtained.

In the next experiments we included $0-4 \mathrm{mM} \mathrm{Mg}^{2+}$ in the incubation medium, so that optimal activity of the vacuolar $\mathrm{H}^{+}$-pump would be supported. In the first instance, we tried to plot ATP uptake as a function of Mg-ATP $\mathrm{AP}^{2-}$ concentrations, but there was no correlation (data not shown). Therefore, we calculated the ATP concentrations unbound to $\mathrm{Mg}^{2+}$ and constructed the graph seen in Fig. 4B. Here the ATP uptake appears to be sigmoidal and non-linear regression was used to calculate the $\mathrm{K}_{\mathrm{m}}$. An apparent $\mathrm{K}_{\mathrm{m}}$ of $0.47 \pm 0.05 \mathrm{mM}$ and a $\mathrm{V}_{\max }$ of $264 \pm 13 \mathrm{pmol} / \mathrm{mg} / 30 \mathrm{~min}$ was calculated together with a Hill coefficient of $3.00=0.75(n=4-12)$.

The next series of experiments were designed to study the characteristics of the transporter using different inhibitors and ionophores both with and without $\mathrm{Mg}^{2+}$. Two controls were included: in the first control ZG were incubated with $0 \mathrm{mM}$ ATP; and in the second control ZG were incubated with 4 $\mathrm{mM}$ ATP and with or without $\mathrm{Mg}^{2+}$. The incubation buffer had a $\mathrm{pH}$ of 6.0, and even in the presence of both inhibitors and ionophores, ZG were relatively stable.

Figure 5A shows the effect of inhibitors and an ionophore in the absence of $\mathrm{Mg}^{2+}$. Figure 5B shows the effect of inhibitors, but now in the presence of $4 \mathrm{mM} \mathrm{Mg}^{2+}$. DIDS has been used in many previous studies as an inhibitor of ATP transport, including VNUT. Here we show that DIDS at $100 \mu \mathrm{M}$ concentration inhibited the uptake of ATP completely, such that it was not significantly different from the $0 \mathrm{mM}$ ATP control. To find the $\mathrm{IC}_{50}$, a dose response curve was made using DIDS concentrations from 1-100 $\mu \mathrm{M}, 4 \mathrm{mM}$ ATP and $0 \mathrm{mM} \mathrm{Mg}^{2+}$ (Fig. 6). The endogenous ATP was subtracted and the data were fitted to the logistic dose-response curve with the equation seen in the figure. $\mathrm{An} \mathrm{IC}_{50}$ of $9.96 \pm 1.16 \mu \mathrm{M}$ was obtained from this curve. This curve also illustrates the narrow range of DIDS concentrations that was needed to completely block the ATP uptake. Evans blue is thought to be a more specific inhibitor for glutamate transporters [30,31], which are in the same family as VNUT [21]. Both figure 5A and B shows that it completely blocked ATP uptake. CCCP is a proton ionophore and its effect depends on $\mathrm{pH}$ differences. In a control buffer of $\mathrm{pH}$ 6.0, its effect appeared to be insignificant (Fig. 5). ARL $67156(0.1 \mathrm{mM})$, the inhibitor of nucleotidase CD39 that is present in the ZG membrane [32], did not show consistent or significant effect on ATP uptake (data not shown). 
The most interesting results were obtained in experiments done in the presence of bafilomycin A1, a vacuolar $\mathrm{H}^{+}$-pump blocker. ATP uptake was only slightly lower in absence of $\mathrm{Mg}^{2+}$, but no significant difference was reached (Fig. 5A). However, when $\mathrm{Mg}^{2+}$ was present, and the pump was active, there was a significant decrease in the ATP uptake with bafilomycin. The solution containing ATP together with $\mathrm{Mg}^{2+}$, each at $4 \mathrm{mM}$, correspond to $0.6 \mathrm{mM}$ ATP unbound to $\mathrm{Mg}^{2+}$. Note that the magnitude of the ATP uptake in the presence of bafilomycin is similar to the uptake seen at $0.5 \mathrm{mM}$ ATP without $\mathrm{Mg}^{2+}$ in Figure 4A.

In order to test possible $\mathrm{K}^{+}$conductance, an experiment with $50 \mathrm{mM} \mathrm{K}$-gluconate was also performed (Fig. 7). The ATP uptake was higher with $50 \mathrm{mM} \mathrm{K}$-gluconate compared to $4 \mathrm{mM} \mathrm{KCl}$ control, however, there was no effect of valinomycin. Figure 7 also illustrates the stimulatory effect of high $\mathrm{Cl}^{-}$concentrations, as $130 \mathrm{mM} \mathrm{Cl}^{-}$stimulated ATP uptake about two-fold compared to $4 \mathrm{mM} \mathrm{Cl}^{-}$. This effect of high $\mathrm{Cl}^{-}$concentration is interesting, as $\mathrm{ZG}$ contain $\mathrm{Cl}^{-}$/anion channels and $\mathrm{Cl}^{-}$is believed to be stimulatory for ATP uptake [21,33,34].

We have also attempted to determine the effect of other nucleotides on ATP uptake. However, the ZG proteome is complex and includes nucleotidases and kinases and thus nucleotides/sides could be easily hydrolysed or interconverted $[3,4,35]$. Therefore, we conclude that this is the reason that we were not able to see significant inhibitory effect on ATP uptake by the addition of ADP or UTP. However, adenosine showed a slight inhibitory effect in three paired experiments $(\mathrm{P}<0.05$, data not shown).

\section{Effect of pH on ATP uptake}

The experiments shown above were performed in buffer at $\mathrm{pH}$ 6.0, where ZG are highly stable. Since $\mathrm{pH}$ could affect both transporters and ion channels, and $\mathrm{H}^{+}$could itself participate in transport, we studied ATP uptake at different $\mathrm{pH}$ values. ZG proved to be relatively stable at higher $\mathrm{pH}$, probably due to low ionic strength of the buffer used.

Figure 8 shows that higher exogenous $\mathrm{pH}$ resulted in significantly higher ATP uptake both in absence (A) and in the presence of $\mathrm{Mg}^{2+}$ (B). A different buffer compared to control SME buffer was used here in order to buffer $\mathrm{pH}$ over a large range, but similar results were obtained when using the SME buffer (data not shown). In addition, we also used $\mathrm{HCO}_{3}{ }^{-} / \mathrm{CO}_{2}$ buffer at $\mathrm{pH} 6.0$ and 7.2, and the ATP uptake was the same as in Figure 8 (data not shown). The higher ATP uptake with increasing extragranular $\mathrm{pH}$ may be due to increasing outward proton gradient, as intragranular $\mathrm{pH}$ is thought to be relatively acidic [6].

To test whether this $\mathrm{pH}$ effect on ATP uptake was a direct effect of the $\mathrm{pH}$ gradient across the ZG membrane, we added CCCP. Figure 8 shows the effect CCCP, at pH 7.2 and $4 \mathrm{mM} \mathrm{KCl}$ on ATP uptake. In contrast to results in Figure 5, where CCCP had no effect on ZG incubated at pH 6.0, now at $\mathrm{pH} 7.2$ the inhibitor had significant inhibitory effect on ATP uptake compared the control condition $(\mathrm{P}<0.05)$. However, in the presence of $4 \mathrm{mM} \mathrm{Mg}^{2+}$, and hence an active vacuolar $\mathrm{H}^{+}$-pump, the inhibitory effect of CCCP was not detected until $\mathrm{pH} 8(\mathrm{P}<0.05)$. This indicates that the vacuolar $\mathrm{H}^{+}-$ pump is able to compensate for the inhibitory effect of the proton ionophore. Thus, the pump maintains relatively flat $\mathrm{pH}$ dependency of ATP uptake.

The described ATP uptake showed great similarities with the newly characterized VNUT transporter [21]. Therefore, we determined expression of this protein. The Western blot in Figure 9 shows the staining for VNUT in zymogen granules $(\mathrm{G})$, zymogen granule membrane (M) in lane 1 and 2. The pre-absorbed antibody staining is shown in lane 3 and 4 . The theoretical size of VNUT is $48.5 \mathrm{kDa}$ based on amino acid composition. In addition, the positive control CD39, a membrane bound ectonucleotidase, is shown (lane 5-6), and also amylase as negative control (lane 7-8) is included. 


\section{DISCUSSION}

In the present study, we have established preparation of intact pancreatic ZG in which the effect of digestive enzymes was minimized and that were suitable for ATP uptake studies. We present the first direct measurements showing that ZG contain ATP and they accumulate ATP by a transport mechanism sensitive to certain inhibitors and ion gradients. We will consider involvement of VNUT and other transporters and discuss the possible role of ATP release from ZG in regulation of pancreatic function.

The ATP uptake kinetics illustrated in ZG, follows one-stage Michaelis-Menten kinetics with an apparent $\mathrm{K}_{\mathrm{m}}$ of $4.9 \pm 2.1 \mathrm{mM}$ without $\mathrm{Mg}^{2+}$. In the presence of $\mathrm{Mg}^{2+}$ the $\mathrm{K}_{\mathrm{m}}$ is lower being $0.47 \pm 0.05$ $\mathrm{mM}$ and follows a sigmoidal shape with a Hill coefficient of $3.00 \pm 0.75$. Both of these $\mathrm{K}_{\mathrm{m}}$ values for $Z G$ are in the same range as the $K_{m}$ of $2.9 \pm 1.1 \mathrm{mM}$ for chromaffin granules [33] and $1.3 \pm 0.3 \mathrm{mM}$ for synaptic vesicles [34]. The latter study also showed a Hill coefficient of $2.00 \pm 0.17$. These $\mathrm{K}_{\mathrm{m}}$ values are in the same range as the $\mathrm{K}_{\mathrm{m}}$ of $0.8 \mathrm{mM}$ reported in the recent study, where VNUT was characterized in a reconstituted system consisting only of the protein and an artificial membrane [21]. In contrast, non-granular organelles, such as ER and Golgi, have apparent $\mathrm{K}_{\mathrm{m}}$ values in the lower $\mu \mathrm{M}$ range $[36,37]$. It seems that the presence of $\mathrm{Mg}^{2+}$ and an active $\mathrm{H}^{+}$-pump has lowered the apparent $\mathrm{K}_{\mathrm{m}}$ of ATP transport, however, it decreased the maximum transport and some secondary effects of $\mathrm{Mg}^{2+}$ may be involved (see below).

Since there are no specific inhibitors for VNUT, we used DIDS and Evans blue, as also used for characterization of this transporter by Sawada and co-workers [21]. ATP uptake studies on vesicles/granules showed that DIDS has an inhibitory effect with half-maximum in the lower $\mu \mathrm{M}$ range $[21,34,33]$, which is in agreement with our findings on ZG. Evans blue blocked ATP uptake in ZG by nearly $100 \%$. Taken together, our results show the presence of an ATP transporter that has similar characteristics to that of synaptic vesicles and chromaffin granules and we propose that the ZG posses the recently characterized VNUT. Indeed, Western blot shows that the VNUT protein is expressed in ZG.

Returning to ATP uptake in the normal physiological range, bafilomycin A1, a vacuolar $\mathrm{H}^{+}$-pump inhibitor had negligible effect on ATP uptake in the absence of $\mathrm{Mg}^{2+}$. Activity of the pump has been questioned for synaptic vesicles [34] as well as for ZG [7]. Nevertheless, we observed a clear inhibitory effect of bafilomycin when ATP and $\mathrm{Mg}^{2+}$ were present at equimolar amounts, and this speaks in favour for an active pump in ZG. One would expect that the pump would build up relatively positive potentials and acidic $\mathrm{pH}$ inside ZG. Similarly, one would predict that the inward $\mathrm{K}^{+}$flux would build positive potentials. Indeed, we observed significantly higher ATP uptake in $50 \mathrm{mM} \mathrm{K}-$ gluconate (Fig. 7), indicating that the membrane potential was important. However, valinomycin had no further effect under these conditions. Most likely, this is due to high endogenous $\mathrm{K}^{+}$conductance in ZG [7].

Increase in external $\mathrm{pH}$ clearly increased ATP uptake and this effect was less pronounced when the vacuolar $\mathrm{H}^{+}$-pump was active (Fig. 8A and B). These findings indicate that the pump compensates for the proton leak, and that the proton ionophore CCCP has correspondingly smaller effects if the proton pump is active. One explanation for the $\mathrm{pH}$ effect on ATP uptake is that the proton gradient, created by the pump or the imposed transmembrane $\mathrm{pH}$ gradient, creates positive membrane potentials that would stimulate ATP anion uptake. Another possibility is that the ATP uptake might be somehow coupled to outward $\mathrm{H}^{+}$transport. We are not certain whether transport of $\mathrm{H}^{+}$can be directly related to the VNUT system, as it is unlikely that VNUT is an $\mathrm{ATP} / \mathrm{H}^{+}$exchanger [21], although this was speculated by Rudnick in a commentary to the paper [38]. However, we have another related observation that needs to be considered. That is, high extra-granular $\mathrm{Cl}^{-}$also increased ATP uptake (Fig. 7). Stimulatory effect of $\mathrm{Cl}^{-}$may be explained in several ways. First, $\mathrm{Cl}^{-}$can directly stimulate VNUT via an extragranular regulatory site [21]. This has also been reported for both the vesicular glutamate and vesicular excitatory amino acid transporters, which belong to the same family as VNUT [30,39]. Second, $\mathrm{Cl}^{-}$could directly participate in ATP transport. Thirdly, $\mathrm{Cl}^{-}$transporters could 
support the function of VNUT. Actually, ZG contain ClC-3 and ClC-5 channels, both of which are $\mathrm{Cl}^{-}$ $/ \mathrm{H}^{+}$antiporters [40,41]. Therefore, outward $\mathrm{H}^{+}$transport and inward $\mathrm{Cl}^{-}$transport, would lead to increased intragranular $\mathrm{Cl}^{-}$, which may stimulate VNUT. The sensitivity to DIDS could illustrate direct inhibition of VNUT, or alternatively as DIDS is a blocker of many anion channels and transporters, its effect might be related to $\mathrm{Cl}^{-}$transport. Finally, there may be more than one ATP transport system.

We do not know which ATP species the transporter(s) take, but at higher $\mathrm{pH}$, the $\mathrm{ATP}^{4-}$ form would be more dominant than HATP ${ }^{3-}$. It is worth pointing out that the kinetics of ATP uptake appears to follow the free ATP and thereby indicating that it is not $\mathrm{Mg}^{-} \mathrm{ATP}^{2-}$ that is transported. Sawada and coworkers [21] did not see any effect of $\mathrm{Mg}^{2+}$; this might be due to the simplified reconstituted preparation. Bankston and Guidotti on the other hand, reported lower ATP uptake when $\mathrm{Mg}^{2+}$ was present at 1:1 ratio or higher [33].

Zymogen granules accumulate ATP in a concentration-dependent manner. What is the concentration of ATP in ZG? In order to answer this question we need to make some assumptions and enabling calculations. Protein concentrations in ZG are estimated to be in the range of $250-600 \mathrm{mg} / \mathrm{cm}^{3}$ and $50 \%$ of ZG content is aqueous [42]. Hence, we estimate ATP concentration in ZG fluid between 40 and $120 \mu \mathrm{M}$, taking into account that freshly isolated ZG contained $93 \mathrm{pmol} / \mathrm{mg}$ ATP/protein. Following incubation with exogenous, cytosolic-like ATP concentrations, we estimate ATP concentrations between $0.2-0.5 \mathrm{mM}$ in the granule. Even higher concentrations would be seen in ZG incubated at cytosolic-like $\mathrm{pH}$ or $\mathrm{Cl}^{-}$concentrations, and we reach top end calculated $\mathrm{ZG}$ average between $0.5-1.1 \mathrm{mM}$, which may well represent in vivo conditions.

Another factor that might influence ATP concentrations is the NTPDase, CD39, which is found in ZG in proteomics, immunohistochemistry, functional studies and also in this study (Fig. 9) $[4,43,44,45]$. It seems that the active site of CD39 is facing ZG lumen [32], but probably in the intact cell it would be inactive until exocytosis. We cannot be sure that CD39 remains inactive in isolated ZG, although CD39 inhibitor ARL 67156 had no effect. This may simply be due to inability of the inhibitor to be transported into ZG. Overall, it seems that ZG have ATP contents that are lower than those estimated for synaptic vesicles [46] and adrenal chromaffin granules [47]. However, calculated estimates in insulin granules vary between 0.2 and $3.5 \mathrm{mM}$, based on ATP concentration of $17.6 \mathrm{pmol} / \mu \mathrm{g}$ insulin and an insulin concentration of $200 \mathrm{mg} / \mathrm{ml}$ in the granule [15,48,49]. In addition, recent studies on ghost synaptic vesicles [34] arrive to similar values as ours, and all transport studies on various vesicles/granules come up with similar ATP transport kinetics (see above).

The last question is whether zymogen granule ATP concentration is physiologically relevant. Pancreatic juice of rats stimulated with acinar agonist CCK-8 contained $\sim 80 \mathrm{mg} / \mathrm{ml}$ of protein, calculated from paper of Matsumoto and co-workers [50]. Assuming that ATP release is in parallel with digestive enzyme release, we would end up with at least $8 \mu \mathrm{M}$ ATP in the juice. This value is in the range that we have measured earlier using in situ bioimaging of ATP release in acini [1], and this concentration is within the range of $\mathrm{P} 2$ receptor activation on adjacent pancreatic ducts [2] .

Taken together, present data support our hypothesis that ATP release from ZG could be physiologically relevant when ATP is released towards the lumen and stimulates ductal P2 receptors and thus ductal secretion. Nevertheless, we cannot exclude that other ATP release mechanism may exist in both acini and also in pancreatic ducts. Lastly, it may be important to consider ATP and ZG in pathophysiology. In case granules become damaged and leaky, ATP could potentially activate intracellular kinases [51], or if ZG exocytose on basolateral membranes, ATP (and digestive enzymes) could thereby affect other target cells surrounding acini.

In conclusion, the present study shows that ATP is taken up into ZG as a function of exogenous ATP and the transport is sensitive to DIDS, Evans blue, $\mathrm{pH}$ and $\mathrm{Cl}^{-}$concentrations. Some of these characteristics can be ascribed to VNUT that we show is expressed in ZG. We conclude that release 
of ATP from ZG by exocytosis, could account for a significant part of ATP released in purinergic signalling in exocrine pancreas.

\section{AKNOWLEDGMENTS}

We would like to thank Professor Yoshinori Moriyama for providing us with VNUT/Slc17a9 antibody. The technical assistance of Ms. A. V. Olsen is greatly acknowledged.

\section{FUNDING}

The project was supported by Danish Natural Science Research Council [272-05-0420, 09-059772], Novo Nordisk Scholarship Program and Lundbeck Foundation [R17-A1366].

\section{FOOTNOTES}

*To whom correspondence should be addressed: Department of Biology, August Krogh Building Universitetsparken 13, University of Copenhagen, DK-2100 Copenhagen Ø, Denmark

Keywords: ATP release, VNUT, ATP uptake, Zymogen Granules, Pancreas, DIDS

The abbreviations used are: CCCP, Carbonyl cyanide m-chlorophenyl hydrazone; CCK-8, Cholecystokinin octapeptide; CD39, Ecto-5'-nucleotidase; CFTR, Cystic fibrosis transmembrane; DIDS, 4,4'-diisothiocyanatostilbene-2,2'- disulfonic acid; SME, Sucrose plus MES and EGTA buffer; VDAC, Voltage dependent anion channel; VNUT, Vesicular nucleotide transporter; ZG, Zymogen granule; ZGM, ZG membrane.

\section{REFERENCES}

1. Sorensen, Christiane E. and Novak, Ivana. (2001) Visualization of ATP Release in Pancreatic Acini in Response to Cholinergic Stimulus. Use of Fluorescent Probes and Confocal Microscopy. J. Biol. Chem. 276, 32925-32932

2. Hede, S. E., Amstrup, J., Christoffersen, B. C., and Novak, I. (1999) Purinoceptors evoke different electrophysiological responses in pancreatic ducts. P2Y inhibits $\mathrm{K}(+)$ conductance, and P2X stimulates cation conductance. J. Biol. Chem. 274, 31784-31791

3. Rindler, M. J., Xu, C. F., Gumper, I., Smith, N. N., and Neubert, T. A. (2007) Proteomic analysis of pancreatic zymogen granules: identification of new granule proteins. J. Proteome. Res. 6, 2978-2992

4. Chen, X., Walker, A. K., Strahler, J. R., Simon, E. S., Tomanicek-Volk, S. L., Nelson, B. B., Hurley, M. C., Ernst, S. A., Williams, J. A., and Andrews, P. C. (2006) Organellar proteomics: analysis of pancreatic zymogen granule membranes. Mol. Cell Proteomics. 5, 306-312

5. De Lisle, R. C. and Williams, J. A. (1987) Zymogen granule acidity is not required for stimulated pancreatic protein secretion. Am. J. Physiol. 253, G711-G719 
6. Orci, L., Ravazzola, M., and Anderson, R. G. (1987) The condensing vacuole of exocrine cells is more acidic than the mature secretory vesicle. Nature. 326, $77-79$

7. Thevenod, Frank. (2002) Ion channels in secretory granules of the pancreas and their role in exocytosis and release of secretory proteins. Am. J. Physiol. Cell Physiol. 283, C651-C672

8. Sabirov, R. Z. and Okada, Y. (2005) ATP release via anion channels. Purinergic Signal. 1, 311-328

9. Kang, J., Kang, N., Lovatt, D., Torres, A., Zhao, Z., Lin, J., and Nedergaard, M. (2008) Connexin 43 hemichannels are permeable to ATP. J. Neurosci. 28, $4702-4711$

10. Qiu, Feng and Dahl, Gerhard. (2009) A permeant regulating its permeation pore: inhibition of pannexin 1 channels by ATP. Am. J. Physiol. Cell. Physiol. 296, C250-C255

11. Ballerini, P., Rathbone, M. P., Di, Iorio P., Renzetti, A., Giuliani, P., D'Alimonte, I., Trubiani, O., Caciagli, F., and Ciccarelli, R. (1996) Rat astroglial P2Z (P2X7) receptors regulate intracellular calcium and purine release. Neuroreport. 7, $2533-2537$

12. Suadicani, S. O., Brosnan, C. F., and Scemes, E. (2006) P2X7 receptors mediate ATP release and amplification of astrocytic intercellular $\mathrm{Ca} 2+$ signaling. $\mathrm{J}$. Neurosci. 26, 1378-1385

13. Schwiebert, E. M., Egan, M. E., Hwang, T. H., Fulmer, S. B., Allen, S. S., Cutting, G. R., and Guggino, W. B. (1995) CFTR regulates outwardly rectifying chloride channels through an autocrine mechanism involving ATP. Cell. 81, 1063-1073

14. Liu, H. T., Toychiev, A. H., Takahashi, N., Sabirov, R. Z., and Okada, Y. (2008) Maxi-anion channel as a candidate pathway for osmosensitive ATP release from mouse astrocytes in primary culture. Cell Res. 18, 558-565

15. Karanauskaite, J., Hoppa, M. B., Braun, M., Galvanovskis, J., and Rorsman, P. (2009) Quantal ATP release in rat beta-cells by exocytosis of insulin-containing LDCVs. Pflugers Arch. 458, 389-401

16. Jo, Y. H. and Role, L. W. (2002) Coordinate release of ATP and GABA at in vitro synapses of lateral hypothalamic neurons. J. Neurosci. 22, 4794-4804

17. Kreda, S. M., Okada, S. F., van Heusden, C. A., O'Neal, W., Gabriel, S., Abdullah, L., Davis, C. W., Boucher, R. C., and Lazarowski, E. R. (2007) Coordinated release of nucleotides and mucin from human airway epithelial Calu-3 cells. J. Physiol. 584, 245-259

18. Pangrsic, T., Potokar, M., Stenovec, M., Kreft, M., Fabbretti, E., Nistri, A., Pryazhnikov, E., Khiroug, L., Giniatullin, R., and Zorec, R. (2007) Exocytotic release of ATP from cultured astrocytes. J. Biol. Chem. 282, 28749-28758 
19. Lazarowski, E. R., Boucher, R. C., and Harden, T. K. (2000) Constitutive release of ATP and evidence for major contribution of ecto-nucleotide pyrophosphatase and nucleoside diphosphokinase to extracellular nucleotide concentrations. J. Biol. Chem. 275, 31061-31068

20. Kostron, H., Winkler, H., Peer, L. J., and Konig, P. (1977) Uptake of adenosine triphosphate by isolated adrenal chromaffin granules: a carrier-mediated transport. Neuroscience. 2, 159-166

21. Sawada, K., Echigo, N., Juge, N., Miyaji, T., Otsuka, M., Omote, H., Yamamoto, A., and Moriyama, Y. (2008) Identification of a vesicular nucleotide transporter. Proc. Natl. Acad. Sci. U. S. A. 105, 5683-5686

22. Chen, X. and Andrews, P. C. (2008) Purification and proteomics analysis of pancreatic zymogen granule membranes. Methods Mol. Biol. 432, 275-287

23. Chen, X., Ernst, S. A., and Williams, J. A. (2003) Dominant negative Rab3D mutants reduce GTP-bound endogenous Rab3D in pancreatic acini. J. Biol. Chem. 278, 50053-50060

24. Brooks, S. P. and Storey, K. B. (1992) Bound and determined: a computer program for making buffers of defined ion concentrations. Anal. Biochem. 201, 119126

25. Williams, J. A., Chen, X., and Sabbatini, M. E. (2009) Small G proteins as key regulators of pancreatic digestive enzyme secretion. Am. J. Physiol. Endocrinol. Metab. 296, E405-E414

26. Burnham, D. B., Munowitz, P., Thorn, N., and Williams, J. A. (1985) Protein kinase activity associated with pancreatic zymogen granules. Biochem. J. 227, 743751

27. De Lisle, R. C., Schulz, I., Tyrakowski, T., Haase, W., and Hopfer, U. (1984) Isolation of stable pancreatic zymogen granules. Am. J. Physiol. 246, G411G418

28. Thevenod, F., Haase, W., and Hopfer, U. (1992) Large-scale purification of calf pancreatic zymogen granule membranes. Anal. Biochem. 202, 54-60

29. Buck, F. F., Bier, M, and Nord, F. F. (1962) Some properties of human trypsin. Arch. Biochem. Biophys. 98, 528-530

30. Juge, N., Yoshida, Y., Yatsushiro, S., Omote, H., and Moriyama, Y. (2006) Vesicular glutamate transporter contains two independent transport machineries. J. Biol. Chem. 281, 39499-39506

31. Roseth, S., Fykse, E. M., and Fonnum, F. (1995) Uptake of L-glutamate into rat brain synaptic vesicles: effect of inhibitors that bind specifically to the glutamate transporter. J. Neurochem. 65, 96-103 
32. Chen, X., Ulintz, P. J., Simon, E. S., Williams, J. A., and Andrews, P. C. (2008) Global topology analysis of pancreatic zymogen granule membrane proteins. Mol. Cell Proteomics. 7, 2323-2336

33. Bankston, Laurie A. and Guidotti, Guido. (1996) Characterization of ATP Transport into Chromaffin Granule Ghosts. Synergy of ATP and Serotonin Accumulation in Chromaffin Granule Ghosts. J. Biol. Chem. 271, 1713217138-

34. Zalk, R. and Shoshan-Barmatz, V. (2006) Characterization of DIDS-sensitive ATP accumulation in brain synaptic vesicles. FEBS Lett. 580, 5894-5898

35. Yegutkin, Gennady G., Samburski, Sergei S., Jalkanen, Sirpa, and Novak, Ivana. (2006) ATP-consuming and ATP-generating Enzymes Secreted by Pancreas. J. Biol. Chem. 281, 29441-29447

36. Shin, S. J., Lee, W. K., Lim, H. W., and Park, J. (2000) Characterization of the ATP transporter in the reconstituted rough endoplasmic reticulum proteoliposomes. Biochim. Biophys. Acta. 1468, 55-62

37. Puglielli, L., Mandon, E. C., and Hirschberg, C. B. (1999) Identification, purification, and characterization of the rat liver golgi membrane ATP transporter. J. Biol. Chem. 274, 12665-12669

38. Rudnick, G. (2008) Vesicular ATP transport is a hard (V)NUT to crack. Proc. Natl. Acad. Sci. U. S. A. 105, 5949-5950

39. Miyaji, T., Echigo, N., Hiasa, M., Senoh, S., Omote, H., and Moriyama, Y. (2008) Identification of a vesicular aspartate transporter. Proc. Natl. Acad. Sci. U. S. A. 105, 11720-11724

40. Matsuda, J. J., Filali, M. S., Collins, M. M., Volk, K. A., and Lamb, F. S. (2010) The $\mathrm{ClC}-3 \mathrm{Cl}-\mathrm{H}+$ antiporter becomes uncoupled at low extracellular $\mathrm{pH}$. J. Biol. Chem. 285, 2569-2579

41. Picollo, A. and Pusch, M. (2005) Chloride/proton antiporter activity of mammalian CLC proteins $\mathrm{ClC}-4$ and $\mathrm{ClC}-5$. Nature. 436, 420-423

42. Ho, Jenny J. L. and Rothman, S. S. (1983) Protein concentration in the pancreatic zymogen granule. Biochim. Biophys. Acta, Gen. Subj. 755, 457-466

43. Sorensen, C. E., Amstrup, J., Rasmussen, H. N., Ankorina-Stark, I., and Novak, I. (2003) Rat pancreas secretes particulate ecto-nucleotidase CD39. J. Physiol. 551, 881-892

44. LeBel, D. and Beattie, M. (1986) Identification of the catalytic subunit of the ATP diphosphohydrolase by photoaffinity labeling of high-affinity ATP-binding sites of pancreatic zymogen granule membranes with 8-azido-[alpha32P]ATP. Biochem. Cell Biol. 64, 13-20 
45. Sevigny, J., Cote, Y. P., and Beaudoin, A. R. (1995) Purification of pancreas type-I ATP diphosphohydrolase and identification by affinity labelling with the 5'-pfluorosulphonylbenzoyladenosine ATP analogue. Biochem. J. 312, 351-356

46. Dowdall, M. J., Boyne, A. F., and Whittaker, V. P. (1974) Adenosine triphosphate. A constituent of cholinergic synaptic vesicles. Biochem. J. 140, 1-12

47. Hillarp, N. A. (1958) Adenosinephosphates and inorganic phosphate in the adrenaline and noradrenaline containing granules of the adrenal medulla. Acta Physiol. Scand. 42, 321-332

48. Detimary, P., Jonas, J. C., and Henquin, J. C. (1996) Stable and diffusible pools of nucleotides in pancreatic islet cells. Endocrinology. 137, 4671-4676

49. Hutton, J. C. (1982) The internal $\mathrm{pH}$ and membrane potential of the insulin-secretory granule. Biochem. J. 204, 171-178

50. Matsumoto, T., Kanno, T., Seo, Y., Murakami, M., and Watari, H. (1991) Dose effects of cholecystokinin and acetylcholine on phosphorus compounds and secretory responses in isolated perfused pancreas of rat. Jpn. J. Physiol. 41, 483-492

51. Thrower, E. C., Diaz de Villalvilla, A. P., Kolodecik, T. R., and Gorelick, F. S. (2006) Zymogen activation in a reconstituted pancreatic acinar cell system. Am. J. Physiol. Gastrointest. Liver Physiol. 290, G894-G902 


\section{FIGURE LEGENDS}

Figure 1 Immunofluorescent staining of Rab3D in purified ZG. ZG were isolated and stained with the primary antibody against Rab3D and secondary antibody conjugated to Alexa 568. Transmission image is on the left and fluorescent overlay on the right. Scale bar is $5 \mu \mathrm{m}$.

Figure 2 ATP measurements on untreated ZG and the effect of digestive enzymes. ATP measurements with repeated addition of ATP $\left(10^{-6} \mu \mathrm{M}\right)$ shows the difference between assays containing the control buffer only (A) and the same buffer with ZG (B). Luminescence (relative luminescence units - RLU) started out at the same level in both assays. (A) In control experiment without ZG, luminescence increased with every addition of ATP and loss of luminescence with time was relatively low. (B) Relative fast loss of luminescence was seen when the ZG were added at time zero. Further addition of ATP did not lead to recovery of the luminescence signal. However, a second addition of Luciferase/Luciferin increased luminescence to levels seen in control $\mathrm{A}$ at 55 minutes.

Figure 3 Relation between ATP and protein concentrations. ZG were incubated in a control buffer containing $4 \mathrm{mM}$ ATP. Protein was related to ATP in the sample, and the linear regression through zero gave a slope of $406 \mathrm{pmol} / \mathrm{mg}$. There is an equal spreading around the average.

Figure 4 Dependence of ATP uptake on extragranular ATP concentrations and effect of $\mathbf{M g}^{2+}$. (A) ZG were incubated for $30 \mathrm{~min}$ in control buffer $\left(4 \mathrm{mM} \mathrm{KCl}\right.$ at $\mathrm{pH} 6.0$ without $\left.\mathrm{Mg}^{2+}\right)$ and varying total ATP concentrations as indicated. The ATP uptake without $\mathrm{Mg}^{2+}$ was fitted with an EadieHofstee plot ( $\mathrm{n}=6$ ). $\mathrm{K}_{\mathrm{m}}$ was $4.9 \pm 2.1 \mathrm{mM}$ and $\mathrm{V}_{\max }$ was $850 \pm 250 \mathrm{pmol} / \mathrm{mg} / 30 \mathrm{~min}$. (B) $\mathrm{ZG}$ were incubated with different $\mathrm{Mg}^{2+}$ and ATP and concentrations in the ratios $\mathrm{mM}$ (Mg:ATP): 0.5:0.5, 1:1, $2: 2,4: 4,3: 4,2: 41: 4$ and $0.5: 4$. The plot shows on the $\mathrm{x}$-axis ATP unbound to $\mathrm{Mg}^{2+}$. The ATP uptake was fitted with non-linear regression to the Hill equation $(n=4-12) . K_{m}$ was $0.47 \pm 0.05 \mathrm{mM}$ and $V_{\max }$ was $264 \pm 13 \mathrm{pmol} / \mathrm{mg} / 30 \mathrm{~min}$, and a Hill coefficient was $3.0 \pm 0.75$.

Figure 5 Effect of inhibitors on ATP uptake. The first bar in (A) and (B) shows the control incubation experiments with $4 \mathrm{mM}$ ATP, where endogenous ATP is subtracted. In the absence (A) and presence (B) of $\mathrm{Mg}^{2+}(\mathrm{A})$, the following inhibitors were added to test incubations containing 4 mM ATP: DIDS $(100 \mu \mathrm{M})$; Evans blue $(100 \mu \mathrm{M})$; bafilomycin A1 (400 nM); CCCP $(5 \mu \mathrm{M})$. All buffers had $4 \mathrm{mM} \mathrm{KCl}$ and $\mathrm{pH}$ was 6.0. Numbers in columns indicate a number of independent experiments. Asterisks indicate $\mathrm{P}<0.05$ for comparison between control and inhibitor tests.

Figure 6 Effect of DIDS on ATP uptake. ZG were incubated with varying DIDS concentrations. Control buffers with $4 \mathrm{mM} \mathrm{KCl}$ and $\mathrm{pH} 6.0$ were used and exogenous ATP concentration for the incubation was $4 \mathrm{mM}(\mathrm{n}=4-7)$. DIDS inhibited ATP uptake with an $\mathrm{IC}_{50}$ of $9.96 \pm 0.75 \mu \mathrm{M}$ calculated from non-linear regression fit to the logistic dose response curve, with zero value set to 0.01 .

Figure 7 Effect of $\mathrm{Cl}^{-}, \mathrm{K}^{+}$and valinomycin on ATP uptake. Control incubation experiments were with $4 \mathrm{mM}$ ATP and endogenous ATP was subtracted. In addition to $4 \mathrm{mM}$ ATP in test incubations, a buffer with $130 \mathrm{mM}$ NMDG-Chloride, a buffer with $50 \mathrm{mM}$ K-Gluconate with and without valinomycin $(5 \mu \mathrm{M})$ was tested. All buffers also had $4 \mathrm{mM} \mathrm{KCl}$ and $\mathrm{pH}$ was 6.0. Numbers in columns indicate a number of independent experiments. Asterisks indicate $\mathrm{P}<0.05$ for comparison between control and inhibitor tests.

Figure 8 Effect of pH and CCCP on ATP uptake. The buffer were made without $\mathrm{Mg}^{2+}$ (A) or with $\mathrm{Mg}^{2+}$ (B) and included $5 \mathrm{mM}$ MES, $5 \mathrm{mM}$ HEPES, $4 \mathrm{mM} \mathrm{KCl}$ and $4 \mathrm{mM}$ ATP. The $\mathrm{pH}$ was adjusted to given values. Numbers in columns indicate a number of independent experiments. Asterisks indicate $\mathrm{P}<0.05$ of $\mathrm{pH}$ tested compared to control $\mathrm{pH} 6.0$; double-crosses indicate $\mathrm{P}<0.05$ of given $\mathrm{pH}$ with and without the inhibitor. 
Figure 9 Western blot with primary antibody directed against VNUT. Isolated zymogen granules (G) and granular membrane fractions (M) from the same isolation were incubated with the following primary antibodies: VNUT (Lane 1,2), Pre-absorbed VNUT (Lane 3,4), CD39 (Lane 5,6), Amylase (Lane 7-8). The blots are from the same assay. The pre-absorbed antibody has same exposure and film as for VNUT. Secondary antibodies were conjugated to horse-radish peroxidase. Numbers indicate molecular mass in $\mathrm{kDa}$. Blot for VNUT is representative of 3 different experiments. 


\section{Figure 1}

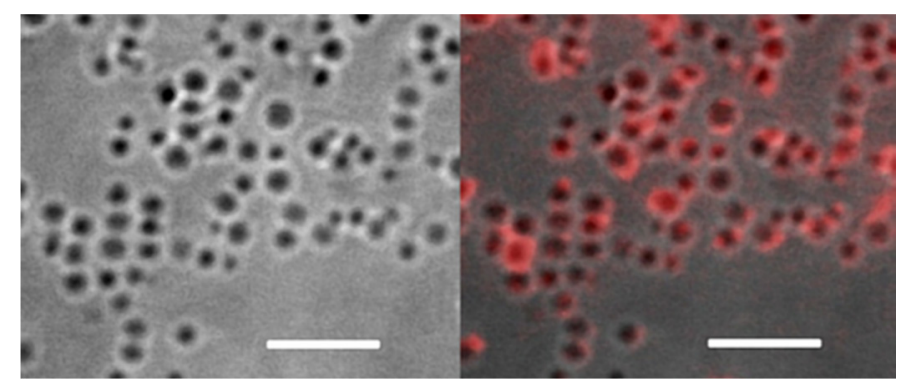




\section{Figure 2}
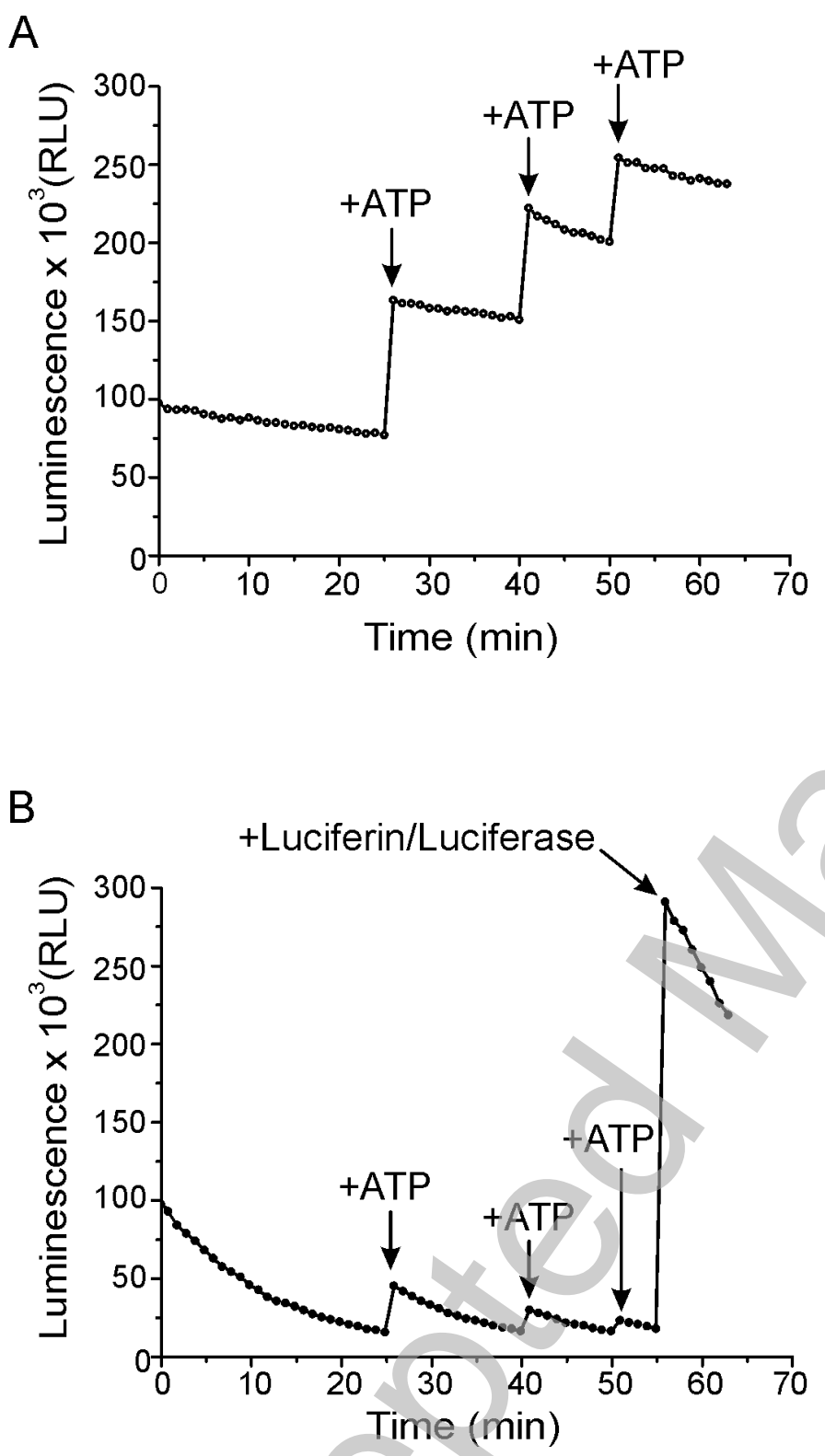


\section{Figure 3}

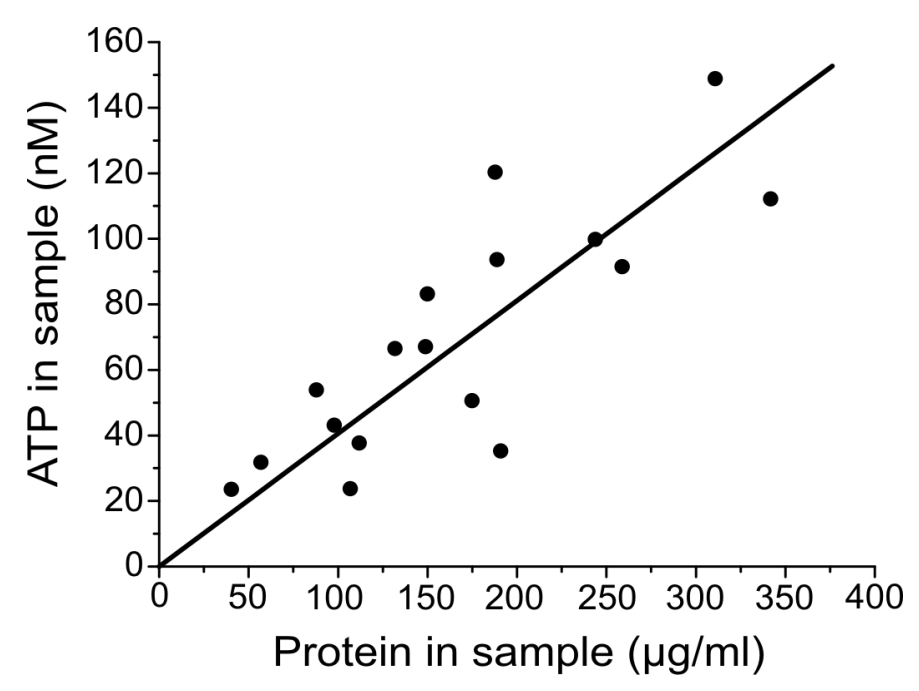




\section{Figure 4}
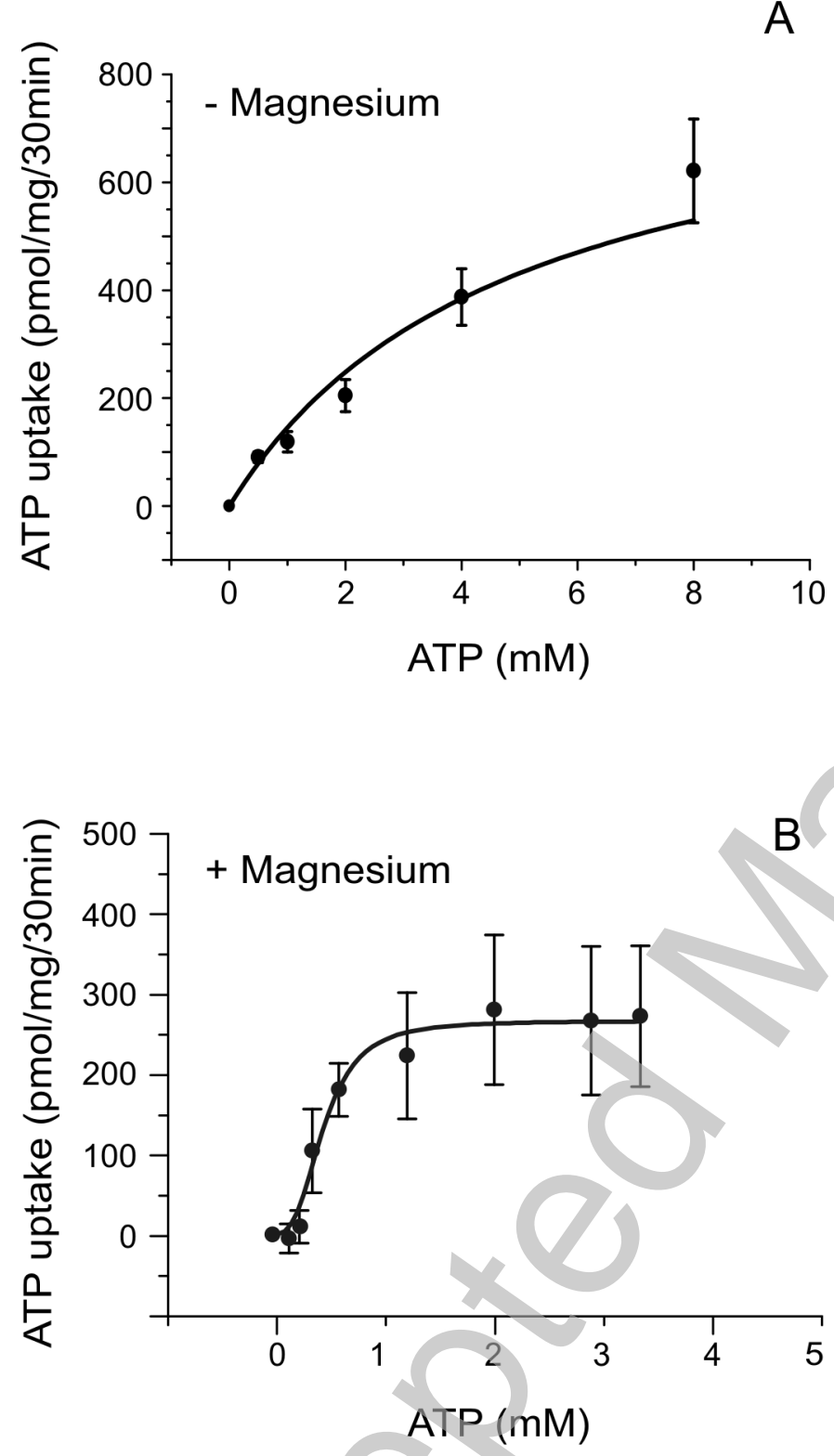


\section{Figure 5}
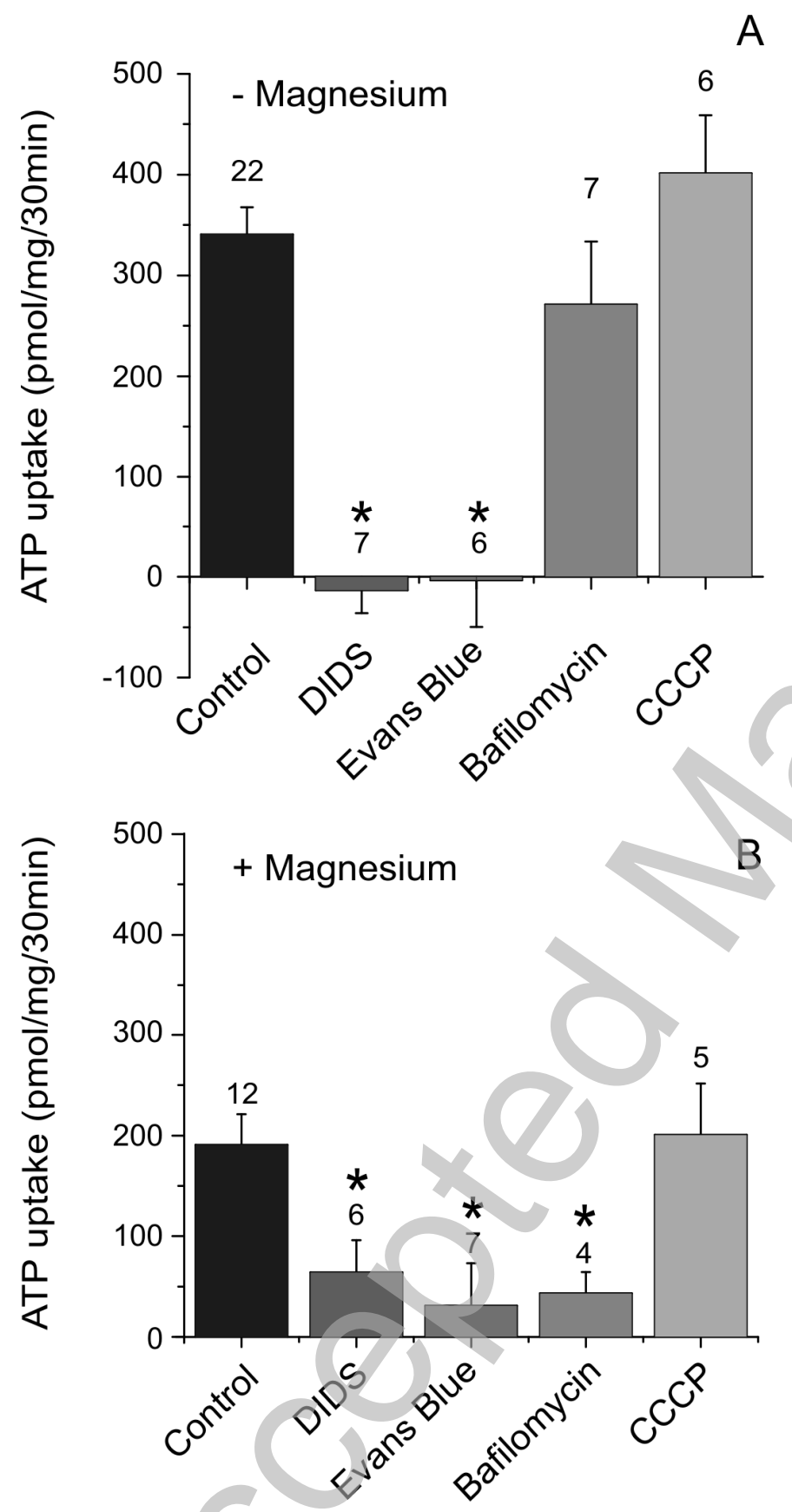


\section{Figure 6}

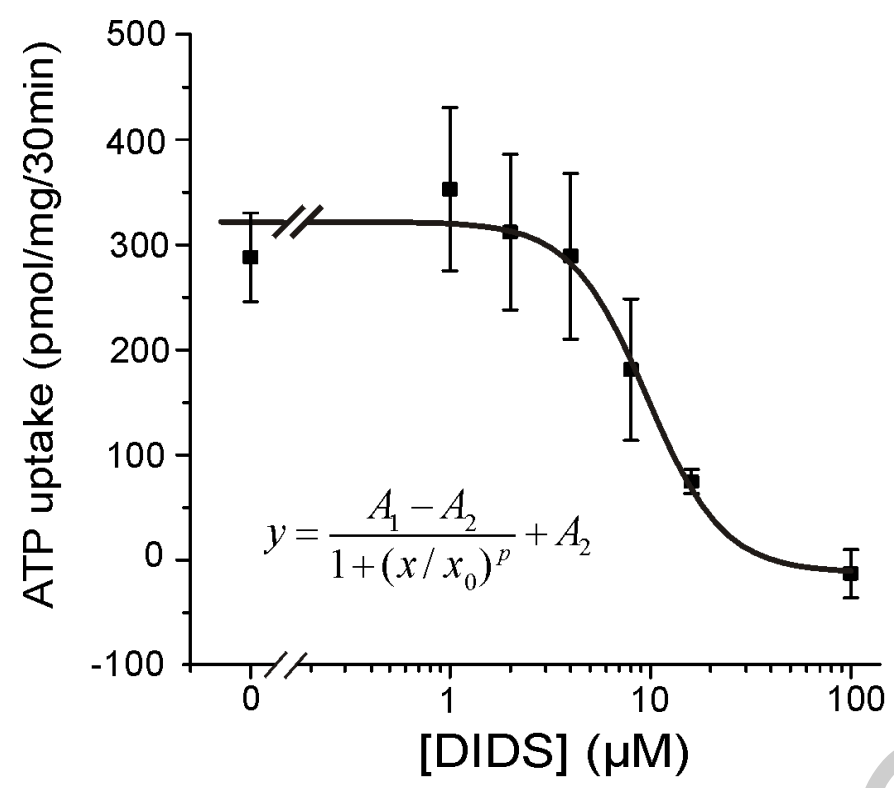




\section{Figure 7}

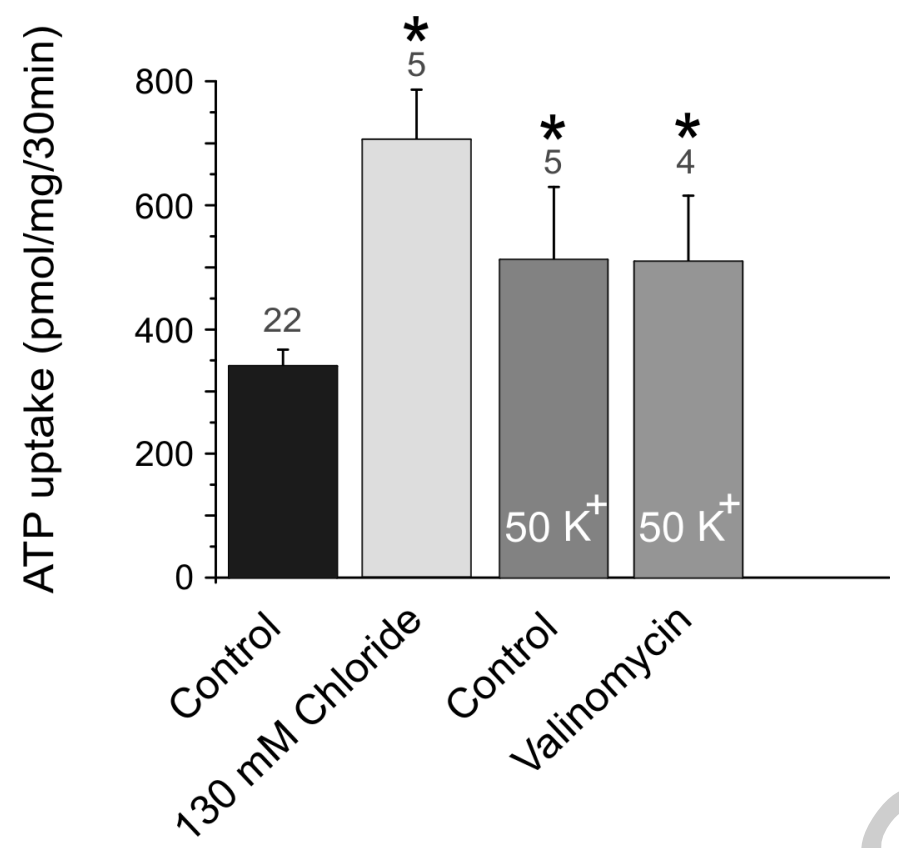




\section{Figure 8}
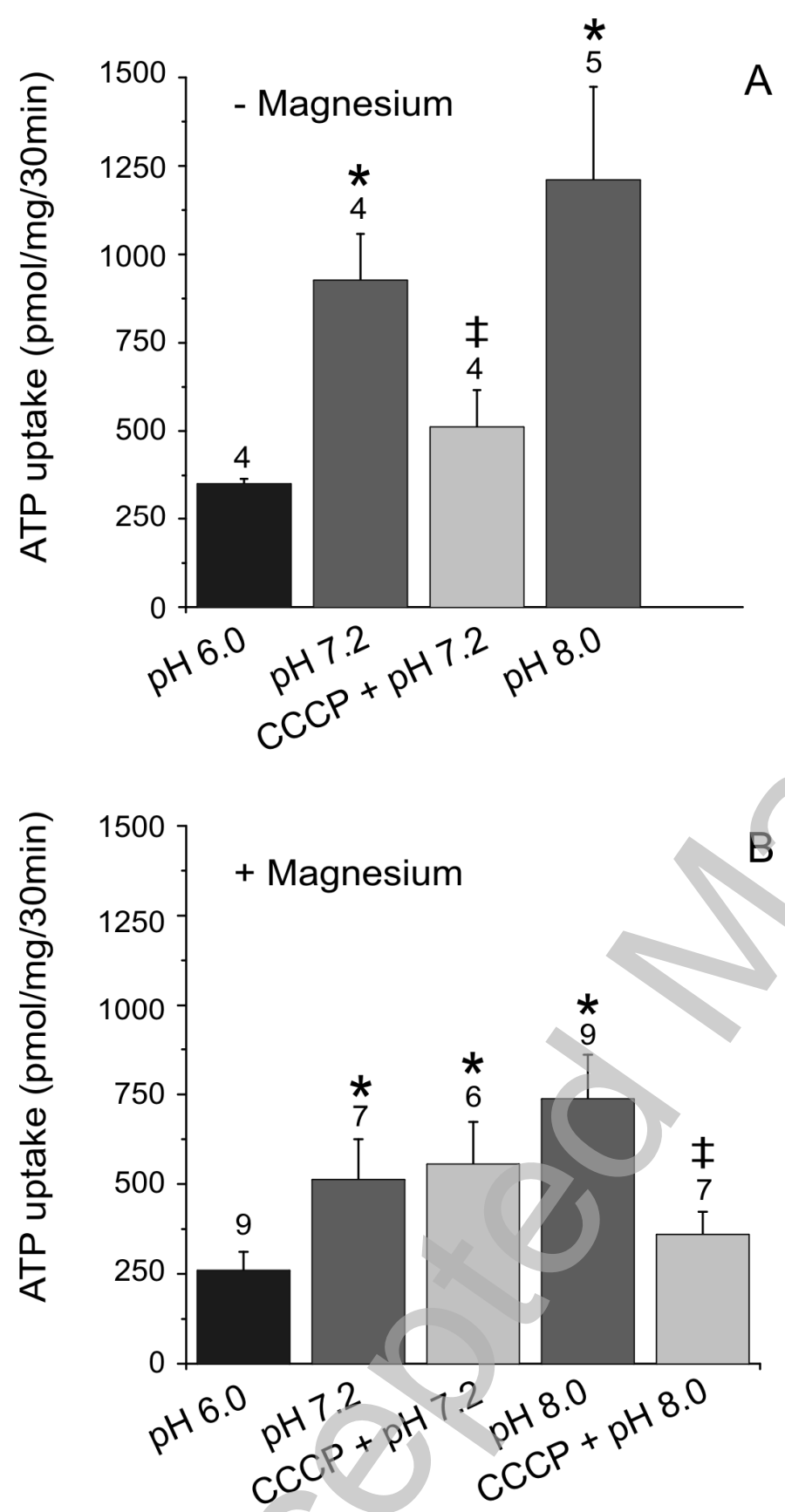


\section{Figure 9}

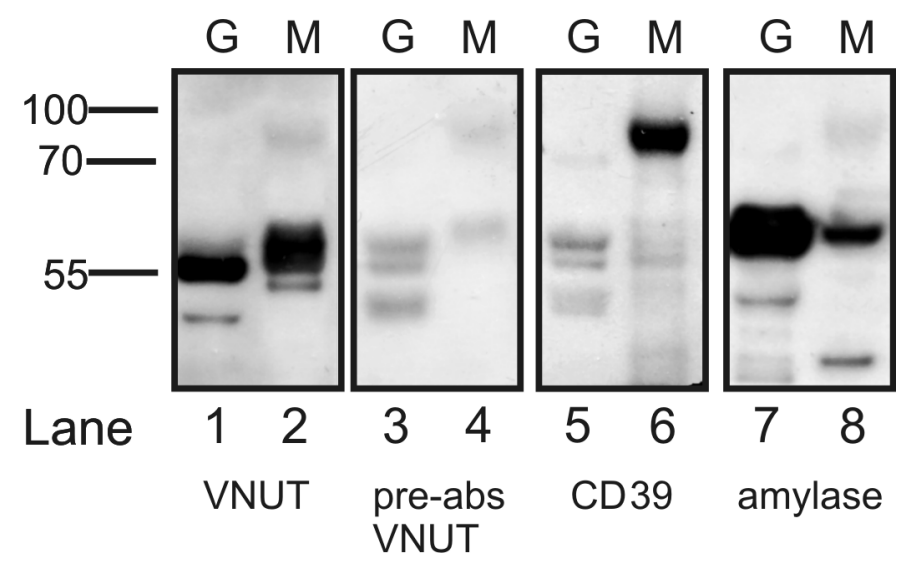

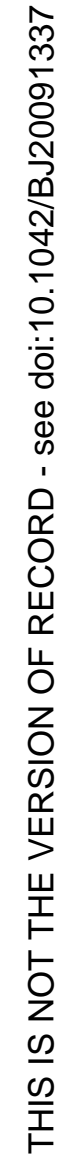

